\title{
日本の設計専門家と非専門家の 内装用木材の認知構造からみる潜在的選択要因
}

\section{LATENT SELECTIVE FACTOR OF JAPANESE DESIGN PROFESSIONALS AND LAYMEN THROUGH ANALYSIS OF COGNITIVE STRUCTURE OF WOOD FOR INTERIOR}

\author{
坂口大史*, 坂井文也**, 北川啓介*** \\ Daishi SAKAGUCHI, Fumiya SAKAI and Keisuke KITAGAWA
}

\begin{abstract}
In the previous study, the latent selective factors of Finnish design professionals and laymen when choosing interior wood for living space were revealed. At least, 8 latent selective factors for Finnish design professionals and laymen were found through the analysis of the cognitive structure of wood for inteior. Following the study, this paper aims to clarify the latent selective factors of Japanese design professionals and laymen. As a result, at least 10 latent selective factors were obtained. These latent selective factors were related to color tone, light and shade of color, heaviness, stiffness, shape and interval of grain, ligneous, familiarity, degree of processing, whiteness and yellowishness. In a future study, the effective measures for the utilization of domestic wood and the guideline to design wooden architecture will be investigated based on both studies from J apanese and Finnish professionals and laymen.
\end{abstract}

Keywords : Latent Selective F actor, Cognitive Structure, Design Professional, Interior Wood, Preference, Principal Component Analysis 潜在的選択要因, 認知構造, 設計専門家, 内装用木材，選好性，主成分分析

\section{1. 研究の背景と目的}

日本では戦後の大造林の結果, 豊富な森林資源が蓄積されてきて いる。その一方で，森林資源が成熟して収穫期を迎えているにもか かわらず，木材自給率は 3 割未満1であり，国内の豊富な森林資源 を十分に活用できていないのが現状である。これら国産材の需給拡 大に関わる課題に対して, 木材利用に関する法整備, 市場の調整, 国内林業の活性化などの取り組みに加えて，木材を使用する設計者 や利用者の視点から, 木材利用についての研究を蓄積していくこと も重要だと考えられる。また, 建築分野における木材需要量は, 日 本の木材総需要量の約 4 割 ${ }^{11}$ を占めている一方で, 建築分野の木材 供給量の約 6 割1)を外国からの輸入材に依存していることから，住 宅分野を中心とした建築用材として国産材の需給拡大に取り組むこ とは，国産材の利用拡大を進める上での鍵になると考えられる。

本稿に関わる一連の研究の背景として, 前稿 2)では, フィンラン ドの設計専門家（以下，専門家）と非専門家を対象として，内装用 木材を用いて比較を行う個別インタビューを行った。インタビュー によって抽出した項目を分析することで, 被験者が木材を認識する 際の着眼点を示寸認知構造に加えて, 住空間に木材を用いる際にど
のような観点から選択しているのかを示寸潜在的選択要因を考察し た。また，本稿と前稿 ${ }^{21}$ の関連論文 ${ }^{31}$ では，評価グリッド法による 個別インタビューを行い，住空間に用いる木材に対する評価を階層 的な論理構造として可視化し，評価傾向によって類型化を行った。

また，本稿に先立ち，前稿 ${ }^{21}$ で対象国としたフィンランドは，世界 有数の森林保有国であり, 自国産の木材を有効活用して先進的な木 造・木質建築に取り組んできている代表的な国の一つである 4) 5)。よ って, 本稿に続く発展的な研究において, 前稿 ${ }^{2)}$ と本稿の分析結果 の比較考察を行い, 両国の被験者の木材に対する認知構造や選択要 因における相違を明らかにすることで，一定の成果を収めてきたフ インランドを例に，日本における自国産の木材の有効活用や木材を 用いたより良い建築を設計するための知見が得られると考えられる。

そこで本稿では，前稿 ${ }^{2}$ と同様に，建築と都市における住空間を 対象として，日本の専門家と非専門家に内装用木材を用いた個別イ ンタビューを行い, 被験者が木材を認識する際の着眼点を示す認知 構造を考察する。さらに，住空間に木材を用いる際の選好性と各被 験者の木材に対する認知構造を合わせて分析することで，木材を住 空間に用いる際の潜在的選択要因を明らかにすることを目的とする。
* 名古屋工業大学大学院工学研究科 博士後期課程 日本福祉大学健康科学部 助教・修士 (工学)

** 国土交通省中部地方整備局木曾川上流河川事務所 修士(工学)

*** 名古屋工業大学大学院つくり領域 准教授・博士 (工学)
Doctoral Candidate, Graduate School of Engineering, Nagoya Institute of Technology: Assist. Prof., Faculty of Health Science, Nihon Fukushi Univ., Master of Engineering Kisogawa-Joryu River Office, Chubu Regional Bureau, Ministry of Land, Infrastructure and Transport, Master of Engineering

Assoc. Prof., Tsukuri College, Graduate School of Engineering, Nagoya Institute of Technology, Doctor of Engineering 


\section{2. 研究対象と方法}

\section{1 調査の概要}

被験者として, 前稿 ${ }^{2)}$ と同様に，3 年以上の実務経験を有する建築 家とインテリアデザイナーを専門家と定義する。また，大学に所属す る学部生及び大学院生と一般人を非専門家と定義する注1)。最終的に, 性別や年齢の偏りを考慮して計 40 名を被験者として選定した (表 1 )。 なお，前稿 ${ }^{2)}$ と同椂に，被験者はボランティアでの参加とした。

続いて，インタビューに使用する木材について，前稿 ${ }^{2}$ と同じ，日 本産の杉白太材及び赤身材，フィンランド産のパイン材及びスプルー ス材の 4 種類の樹種と各木材に対して無垢，ワックス加工，オイル加 工の 3 種類の加工を施した, 計 12 種類の木材注2) を用意した（表 2 ）。

本稿における個別インタビューは，2014 年 10 月～2015 年 1 月に 実施し,インタビューの実施環境の概要を図 1 にまとめた。インタ ビューを行った本学内の部屋は, 横幅 $4100 \mathrm{~mm} \times$ 奥行き $3470 \mathrm{~mm} \times$ 高さ $2900 \mathrm{~mm}$ で，昼光色の照明（2つの光源で計 17001x）の下，木材 表面上の照度が一定 (5001x) になるように机の上に設置した。なお, 都合上，学内でのインタビューが実施できない被験者は，各設計・ デザイン事務所などにおける，本学内で用いた部屋と同程度の大き さ，照明環境（照明の色，机上の照度など）の個室を用意し，室内 環境に極端な差が出ないように配慮してインタビューを実施した。

\section{2 インタビューの手順}

前稿 ${ }^{2)}$ と同様に, 異なる 3 つの対象を組み合わせて被験者に提示し,

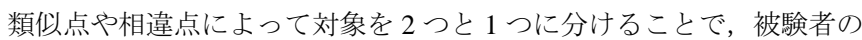
自発的な着眼点を把握する技法である「3 個組技法」を用いた個別イ ンタビューを行う。これにより, 各被験者が木材を認識する際の項目 （以下，認識項目）を抽出した上で，各分析を行う手順とした注3)。 まず，全被験者への共通の教示として，木材に対する被験者の認識 や着眼点を把握する趣旨であることを伝えた。続いて，提示する各組 の木材を自由に観察するように指示した。また，各質問に対して深く 考え込まず，直感的に答えるように指示した。さらに，各組の質問に 対する回答が複数存在する場合は, 複数回答するように指示し, 回答 が他の組と重複する場合，回答の重複を許可する旨を伝えた。

インタビューを行う際の注意点として, 被験者へ質問する際に，回 答を誘導することなく，被験者の自発的な回答を記録するように努め た。また，被験者による質問のうち，提示する木材の樹種や加工方法 など，分析結果に影響を及ぼすと想定される質問事項には回答しなか った。表 3 に一連のインタビューの手順をまとめた。なお, インタビ ュー全体の所要時間はひとりあたり $30 \sim 50$ 分であった。以下に本稿 における分析の流れと各分析の意図を整理して段階的に示す。

1）各被験者が指摘した認識項目を意味内容や類似性によって，小 分類, 大分類に分類する注 61 。次に, 各認識項目の指摘回数注 71 から, 全体的な認識傾向の分析を行う。続いて，認識項目の指摘回数に よるコレスポンデンス分析を行い，各属性の認識傾向を把握する。

2）認識項目の点数化の結果から, 被験者の属性毎に平均点を算出し て主成分分析を行う。続いて，主成分分析により得られた結果のう ち，主成分負荷量から各属性と認識の主成分軸との関係，主成分ス コアから各木材と主成分軸の関係を分析し，認知構造を把握する。

3）各木材に対する好夕についての平均点も同様に算出し，各認識 項目の平均点と合わせて被験者の各属性における相関分析を行う ことで，選好性と認識項目との相関を分析する。
表 1 被験者の属性

\begin{tabular}{|c|c|c|c|c|}
\hline 属性 & \multicolumn{2}{|r|}{ 専門家 } & \multicolumn{2}{|c|}{ 非専門家 } \\
\hline 年代 & 建築家 & インテリアデザイナー & 学生 & 一般人 \\
\hline 20 代 & 0人 $(0$ 人) & 0人 $(0$ 人) & 10人 (5人) & 0人 $(0$ 人) \\
\hline 30 代 & 4人 (2人) & 3人 (2人) & 0人 $(0$ 人) & 3人 $(2$ 人) \\
\hline 40 代 & 3 人 $(2$ 人) & 3人 (1人) & 0人 $(0$ 人) & 3人 (1人) \\
\hline 50 代 & 3人 (1人) & 4人 $(2$ 人) & 0人 (0人) & 4人 $(2$ 人) \\
\hline 計 & 10人 (5人) & 10人 (5人) & 10人 (5人) & 10 人 $(5$ 人) \\
\hline
\end{tabular}

※括弧内の数字は女性の数を示す。

表 2 インタビューに使用した木材

\begin{tabular}{|c|c|c|c|c|}
\hline J. & 樹種と加工 & & No. & 樹種と加工 \\
\hline 1 & 杉白太 無垢 & (杉白無) & 7 & ワックス加工 (スワ) \\
\hline 2 & パイン 無垢 & (パ無) & 8 & ワックス加工 \\
\hline 3 & スプルース 無垢 & (又無) & 9 & オイル加工 \\
\hline 4 & 杉赤身 & 杉赤無) & 10 & パイン オイル加工 \\
\hline 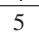 & 杉白太 & 杉白ワ) & 11 & スプルース オイル加工 \\
\hline 6 & パイン ワックス加工 & (パワ) & 12 & 杉赤身 オイル加工 \\
\hline
\end{tabular}

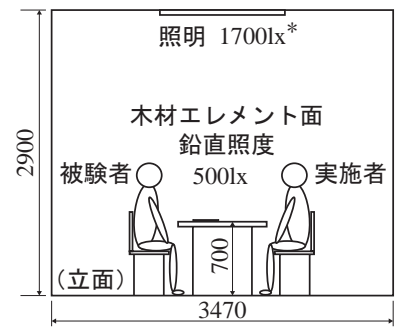

*照明には 2 つ光源を含む。

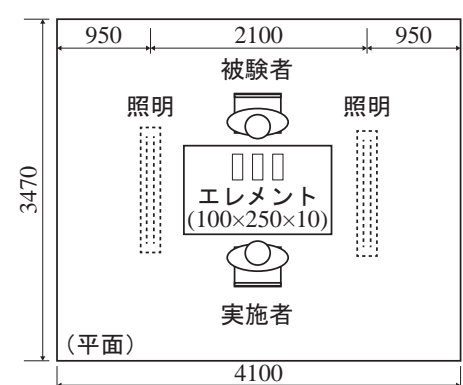

図 1 インタビュ一実施環境の概要 $(\mathrm{mm})$

\section{表 3 個別インタビューの手順}

\section{1. 研究趣旨の説明と教示}

本研究の趣旨と全被験者共通の教示内容を伝える。ここで, 個別のインタビュー を始める前の質問等があれば回答する。

\section{2. 木材サンプルの提示}

木材の特徴に偏りがないように,あらかじめ組み合わせた $3 つ 1$ 組の木材 (表 9) を被験者に提示し，提示した木材を自由に観察するように指示する。

\section{3. 提示された木材サンプルの区分}

提示した木材に関して, 各木材の類似点もしくは相違点によって, 3 つの木材 を2つと 1 つ分けるように指示する。

4. 区分の理由となる認識項目の抽出

区分された木材に関して，3つの木材を 2 つと 1 つに区分した際の理由を可能 な限り述べるように指示し, 認識項目として抽出する。

\section{5. 各被験者における認識項目と好みに対する点数化}

抽出した認識項目毎に各木材に対して 1 5 点の 5 段階評価で点数注 4) を与え るように指示する。また，全被験者の共通項目として，「住空間に用いる際の 好ましさ注 5 )」についても，同様に 1 5 点で点数を与えるように指示する。

4）以上の主成分分析，各木材に対する選好性，選好性と認識項目 との相関分析から得られた結果より，被験者の各属性における潜 在的選択要因を考察し，結論にまとめる。

\section{3. 各属性における認識項目の指摘回数と木材に対する認識の傾向 3.1 各属性における認識項目の指摘回数}

専門家と非専門家の認識項目を分類し，各分類の指摘回数注 8) を集 計した。続いて, 被験者の各属性と認識項目のクロス集計の $x^{2}$ 検定 において有意な結果 $(p<0.05)$ が得られたことから, 残差分析を行っ た結果も合わせて各属性における指摘回数をまとめた（表 4 ）。

認識項目の指摘回数における全体の傾向として，\{色相 $\},$ 【心象】 の \{印象\} の指摘回数が多いことから，専門家，非専門家共に木材 
のもつ色の特徴や木材全体から受ける印象をもとに木材を認識する 傾向が読みとれる。続いて, \{密度 $\},\{$ 重量 $\},\{$ 形状 $\}$ の指摘回数 が多いことから，木目の間隔や形などの視覚的な情報や木材の物理 的な重さによって木材を認識する傾向が読みとれる。

また，男女の指摘回数における特徵として，\{色相 $\}$ や \{重量 $\}$ は 共通して多いが，男性では，\{形状\}，\{用途\},【心象】の $\{$ 印象 $\}$ の 指摘回数が女性に比べて多く,女性では, \{平滑 $\}$ と表面】の $\{$ 印象 $\}$ の指摘回数が男性に比べて多い。これより，男性は木材のもつ木目 や木材が使用される用途に加えて，木材全体から受ける印象に着目 しているのに対し，女性は木材の表面の滑らかさに加えて，表面か ら受ける印象に着目している点に違いが読みとれる。

次に，専門家と非専門家の指摘回数における傾向として，建築家で は \{色相\}において有意な差（ $p<0.05 ）$ がみられた。また，インテア デザイナーでは, $\{$ 加工 $\},\{$ 強度 $\},\{$ 用途 $\}$,【心象】の $\left\{\mathrm{F}^{2}\right.$ 象 $\}$ にお いて有意な差 $(p<0.05)$ がみられた。これより, 専門家は木材のもつ 色味に加えて, 表面の加工度合い, 強度や用途，木材の全体的な印 象に着目していることが読みとれる。続いて，非専門家における学 生では $\{$ 明度 $\},\{$ 平滑 $\}$ において有意な差 $(p<0.05)$ がみられた。一方, 一般人では, \{品質\}の指摘回数において有意な差 $(p<0.05)$ がみられた。

\section{表 4 認識項目の分類と指摘回数}

\begin{tabular}{|c|c|c|c|c|c|c|c|}
\hline \multicolumn{2}{|c|}{ 分類 } & 認識項目 & \multicolumn{2}{|c|}{ 専門家 } & \multicolumn{2}{|c|}{ 非専門家 } & \multirow[b]{2}{*}{ 計 } \\
\hline 大分類 & 小分類 & 発言例 & 建築家 & $\begin{array}{l}\text { インテリア } \\
\text { デザイナー }\end{array}$ & 学生 & 一般人 & \\
\hline \multirow{5}{*}{ 【色】 } & $\{$ 色相\} & 茶色, 黄色, 白色 & $30(15)^{*}$ & $19(11)$ & $15(8)^{*}$ & $16(5)$ & $80(39)$ \\
\hline & $\{$ 明度 $\}$ & 明るい色 & $0(0)$ & $1(1)$ & $5(4) *$ & $2(0)$ & $8(5)$ \\
\hline & $\{$ 濃度\} & 濃い色 & 4(3) & $4(3)$ & $8(4)$ & $6(2)$ & $22(12)$ \\
\hline & $\{$ 配色\} & 色が並べたときにきれい & $0(0)$ & $0(0)$ & $1(0)$ & $0(0)$ & $1(0)$ \\
\hline & $\{$ 印象 & 人工色, 有色 & $8(4)$ & $7(4)$ & $5(2)$ & $3(2)$ & $23(12)$ \\
\hline \multirow{5}{*}{ 【模様】 } & \{形状\} & $\begin{array}{l}\text { 木目が丸っこい, 三角 } \\
\text { の模様, 川のような木 } \\
\text { 目, まっすぐな木目 }\end{array}$ & $6(4)$ & $8(2)$ & $8(3)$ & $8(1)$ & $30(10)$ \\
\hline & $\{$ 密度\} & 木目が密，規則的な木目 & $7(4)$ & $3(1) *$ & $12(8)$ & $10(4)$ & $32(17)$ \\
\hline & \{明瞭\} & 木目のコントラストが強い & $2(2)$ & $3(0)$ & $3(0)$ & $1(1)$ & $9(3)$ \\
\hline & $\{$ 印象\} & $\begin{array}{l}\text { 木目がきれい, 木目が } \\
\text { 面白い,人工的な木目, } \\
\text { 木目が和風 }\end{array}$ & $7(5)$ & $1(0)$ & $6(3)$ & $1(0)$ & $15(8)$ \\
\hline & $\{$ 価值 $\}$ & 木目が美しい & $1(0)$ & $0(0)$ & $0(0)$ & $0(0)$ & $1(0)$ \\
\hline \multirow{5}{*}{ 【表面】 } & $\{$ 加工\} & 塗装, 加工, 素地 & $7(4)$ & $10(2)^{*}$ & $2(2)$ & $1(0)$ & $20(8)$ \\
\hline & $\{$ 光沢\} & 光沢 & $0(0)$ & $1(1)$ & $2(1)$ & $2(1)$ & $5(3)$ \\
\hline & \{平滑\} & $\begin{array}{l}\text { でこぼこがある,つるつ } \\
\text { る,触り心地が油つぼい }\end{array}$ & $5(1)$ & $0(0)$ * & $12(8)^{* *}$ & $6(4)$ & 23(13) \\
\hline & 污れ・傷 & 傷が目立つ & $0(0)$ & $0(0)$ & $1(0)$ & $0(0)$ & $1(0)$ \\
\hline & $\{$ 印象\} & $\begin{array}{l}\text { ベたっとした, 触って } \\
\text { 抵抗を感じない }\end{array}$ & $2(1)$ & $0(0)$ & $3(3)$ & $0(0)$ & $5(4)$ \\
\hline 【香気】 & $\{$ 印象\} & 人工的なにおい & $0(0)$ & $1(0)$ & $1(0)$ & $0(0)$ & $2(0)$ \\
\hline \multirow{8}{*}{ 【特質】 } & $\{$ 重量\} & 重い, 素材が密 & $8(4)$ & $6(5)$ & $10(4)$ & $8(4)$ & $32(17)$ \\
\hline & $\{$ 強度 $\}$ & 堅い，反れそう & $1(1)$ & $5(2) *$ & $3(1)$ & $0(0)$ & $9(4)$ \\
\hline & $\{$ 汎用 $\}$ & 空間を選ぶ, 適応できる & $2(0)$ & $1(1)$ & $0(0)$ & $0(0)$ & $3(1)$ \\
\hline & \{用途\} & $\begin{array}{l}\text { 学校の机にありそう, } \\
\text { まな板みたいな, 壁に } \\
\text { 使う,レストラン, 旅館 } \\
\text { おじいちゃんの家の } \\
\text { イメージ, 新築のイメ } \\
\text { ージ, 素足の空間 }\end{array}$ & $0(0)^{*}$ & $9(2)^{* *}$ & $5(0)$ & $2(0)$ & $16(2)$ \\
\hline & $\{$ 品質 $\}$ & $\begin{array}{l}\text { 安定感がある,頼りない, } \\
\text { 状態が良い }\end{array}$ & $0(0)$ & $0(0)$ & $1(0)$ & $6(4)^{* *}$ & $7(4)$ \\
\hline & 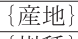 & 外国産 & $1(0)$ & $0(0)$ & $1(0)$ & $0(0)$ & $2(0)$ \\
\hline & $\{$ 樹種\} & 杉, 松, 成長の早い木 & $3(1)$ & $2(0)$ & $2(1)$ & $0(0)$ & $7(2)$ \\
\hline & $\{$ 乾燥\} & $\begin{array}{l}\text { しっとり, 乾燥した, } \\
\text { 吒いた音が高い }\end{array}$ & $4(2)$ & $0(0)$ & $3(1)$ & $0(0)$ & $7(3)$ \\
\hline \multirow[t]{2}{*}{ 【心象】 } & $\{$ 印象\} & $\begin{array}{l}\text { 時間が経っている, 新 } \\
\text { 鮮な木を感じる, 馴染 } \\
\text { みのある, 和風, 女性, } \\
\text { 成功者, 優柔不断, ど } \\
\text { っしとした, 清潔感 }\end{array}$ & $18(7)$ & $33(8)^{* *}$ & $12(6)$ & $14(4)$ & $77(25)$ \\
\hline & $\{$ 価值\} & 魅力のある & $0(0)$ & $1(0)$ & $0(0)$ & $0(0)$ & $1(0)$ \\
\hline
\end{tabular}

\begin{tabular}{|l|l|c|c|c|c|}
\hline$\chi^{2}$ 值 $=133$ ，自由度 $=75, p=0.000<0.05$ 計 & $116(56)$ & $115(46)$ & $116(63)$ & $91(32)$ & $438(197)$ \\
\hline
\end{tabular} ※括弧内の数字は女性の指摘回数を示す。 $* *: \mathrm{p}<0.01, *: \mathrm{p}<0.05$
これより，非専門家は，木材のもつ色の明るさ，木材表面の滑らか さに加えて，木材の品質に着目していることが読みとれる。

\section{2 木材に対する各属性の認識傾向}

被験者の各属性と認識項目の小分類の 0/1 型データによるコレスポ ンデンス分析を行い，各属性の内装用木材を認識する際の着眼点に ついて分析を行う注9)。続いて, コレスポンデンス分析によって得ら れた 1 つ目の成分である第 1 軸 $(p<0.05)$ と 2 つ目の成分である第 2 軸（ $p<0.05 ）$ が統計的に有意な結果を示したことから，第 1 軸と第 2 軸の行列スコアをもとに，ward 法，ユーグリッド距離によるクラス ター分析によって，距離の近しい項目のグルーピングを行った（図 2 )。さらに，被験者の各属性と認識項目の関連の強さをグラフ上の 距離に転換して模式化し, クラスター分析による分類結果も含めた散 布図を作成することで，木材に対する認識傾向の分析を行う（図 3 ）。 まず，クラスター分析の結果において，被験者の各属性と同じク ラスターに含まれた認識項目は，各属性の木材に対する認識に対し てより結びつきの強い項目であると考えられる。また，クラスター

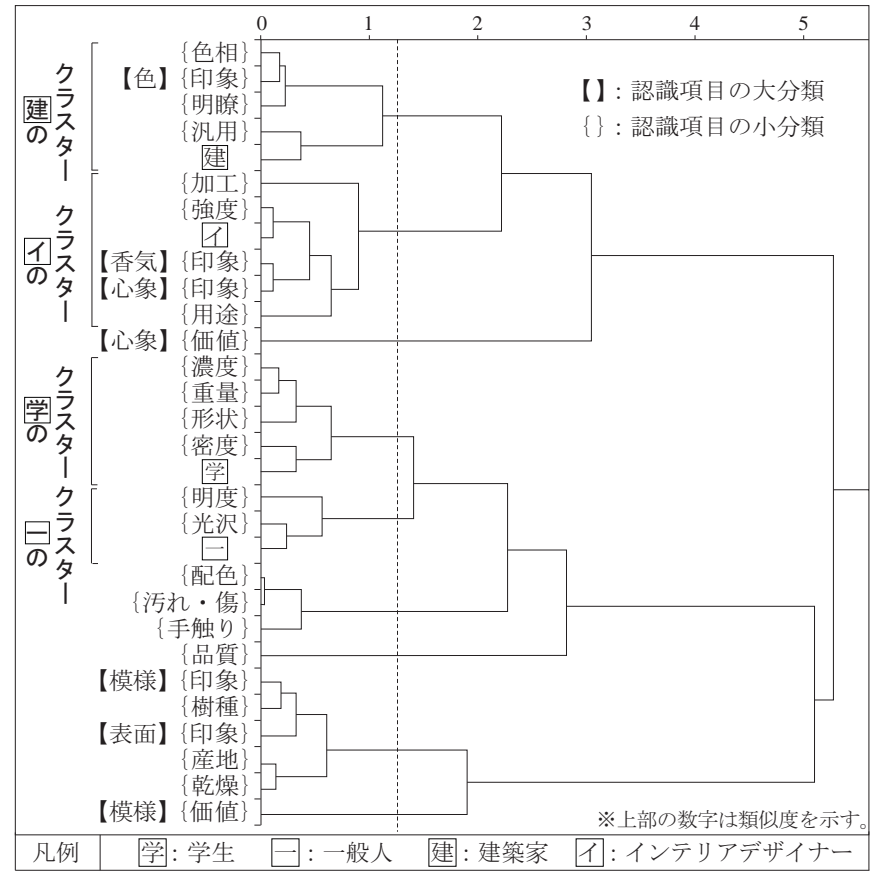

図 2 クラスター分析によるデンドログラム

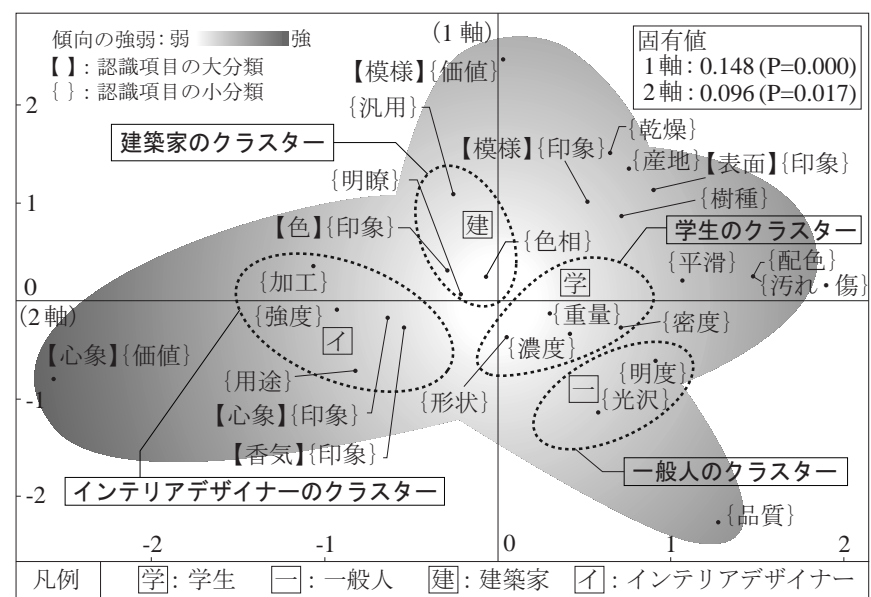

図 3 各属性における木材の認識傾向 
分析により得られたデンドログラムの結果から, 専門家の建築家と インテリアデザイナーが比較的近いクラスターに分類されており, 学生と一般人が近いクラスターに分類されていることから, 専門家, 非専門家においてそれぞれの認識傾向が近いことが読みとれる。

続いて, 散布図より, 学生では $\{$ 濃度 $\},\{$ 重量 $\},\{$ 形状 $\},\{$ 密度 $\}$ が同じクラスターに属することから, 学生は木材の物理的な重さ, 木 材のもつ模様の間隔や形状に加えて, 色の濃淡を重視して木材を認識 しているといえる。一般人では $\{$ 明度 $\},\{$ 光沢 $\}$ が同じクラスターに 属することから, 一般人は木材の表面の艶などの光沢や木材のもつ色 の明るさを重視して木材を認識しているといえる。

建築家では $\{$ 色相 $\}$, 【色】の $\{$ 印象 $\},\{$ 明瞭 $\},\{$ 汎用 $\}$ が同じクラスター に属することから，建築家は木材の色合い，色による印象，模様の 明瞭さに加えて, 木材を空間に用いる際の汎用性を重視して木材を 認識しているといえる。インテリアデザイナーでは $\{$ 加工\}, \{強度\}, 【香気】の $\left\{\mathrm{N}^{2}\right.$ 象\}, \{用途\}, 【心象】の $\{$ 印象 $\}$ が同じクラスターに 属することから，インテリアデザイナーは木材の用途や木材の物理 的な強度に加えて, 木材全体がもたらす印象, 木材のもつにおいが もたらす印象を重視して木材を認識しているといえる。

\section{4. 主成分分析による認知構造の把握}

各認識項目において算出した平均点によって主成分分析を行うこと

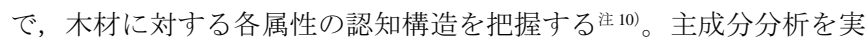
行する際，統計的に正確さを期待できる標準偏差や平均点を計算す るため, 3 人以上が指摘した項目とその点数を用いた。

続いて, 主成分分析から得られる各認識項目の主成分負荷量と各木 材の主成分スコアに基づいて, 各属性における認識傾向を考察する。 なお, 各主成分の解釈には主成分負荷量が 0.60 以上の項目を用い, 項目が少なく客観的な解釈ができない場合，第 1 主成分では負荷量が 0.55 以上，第 2,3 主成分では 0.50 以上の項目も含めて解釈した。

\section{1 学生における主成分負荷量と主成分スコア}

学生における主成分分析の結果を散布図にまとめた（図 4)。各主 成分の寄与率をみると，第 3 主成分までの累積寄与率が $80.0 \%$ を超 えることから，第 $1 ， 2 ， 3$ 主成分により認識軸の分析を行う。

主成分負荷量の散布図をみると, 第 1 主成分軸の方向において, 「明るい色」,「新鮮な」,「木目が密」,「でこぼこがある」などの順に, 正の大きい值となった。また，「時間が経っている」，「つるつる」の 順に負の大きい值となった。正の值にみられた項目は，より自然な 表面状態に近い無垢材に加えて, 密な木目で重い木材に共通した項 目であると考えられる。負の值にみられた項目は，表面が滑らかな 状態であり, 経年変化した印象を与える木材に共通した項目である と考えられる。これより，第 1 主成分は，木材の表面性状及び経年 変化に関する軸と位置づけられる。続いて，第 2 主成分軸の方向に おいて,「茶色」で正の大きい值となり,「黄色」,「重い」で負の大 きい值となった。正の値にみられた項目は，杉赤身材のもつ特徴を 示し，負の值にみられた項目は，パイン材やスプルース材のもつ特 徵を示していると考えられる。これより，第 2 主成分軸は，木材の もつ色味と重さに関する軸と位置づけられる。さらに，第 3 主成分 軸の方向において,「濃い色」,「シンメトリー」,「木目が密」で正の 大きい值となった。これより第 3 主成分軸は，木材のもつ色の濃淡 と木目間隔及び形状に関する軸と位置づけられる。

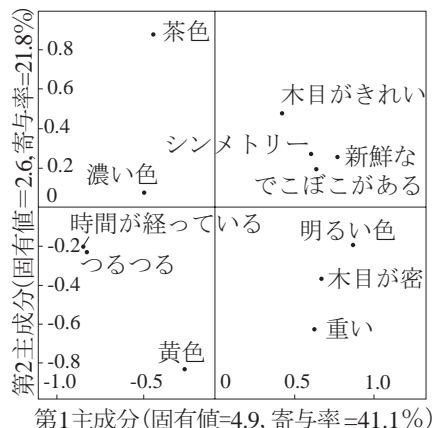

認識項目の主成分負荷量

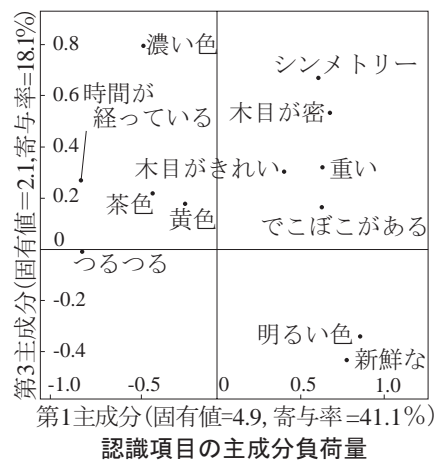

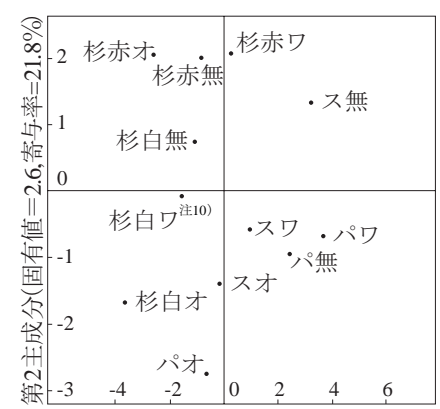

第 1 主成分 $($ 固有值 $=4.9$, 寄与率 $=41.1 \%)$ 木材の主成分スコア

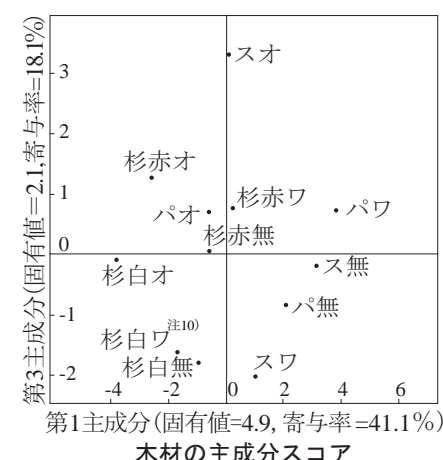

木材の主成分スコア
次に, 主成分スコアの散布図をみると, 第 1 主成分軸の方向にお いて, オイル加工が施された木材と自然な状態に近い無垢の木材及 びワックス加工が施された木材が対極に位置している。続いて，第 2 主成分軸の方向において, 茶系統の色が強い杉赤身材と, オイル加 工が施されて黄色味が増したパイン材とスプルース材が対極に位置 している。さらに, 第 3 主成分軸の方向において, 元々濃い色をも つ木材や加工によって色が濃くなった木材と, 無垢の木材やワック ス加工が施された色の淡い木材が対極に位置している。以上の結果 から，学生における各主成分軸の解釈の妥当性が示された。

\section{2 一般人における主成分負荷量と主成分スコア}

一般人における主成分分析の結果を散布図にまとめた（図 5 )。一 般人の主成分の寄与率をみると, 第 2 主成分までの累積寄与率が 80.0\%を超えることから，第 1，2 主成分により認識軸の分析を行う。

主成分負荷量の散布図をみると, 第 1 主成分軸の方向において, 「木を感じる」, 「重い」,「白色」,「木目が密」の順に正の大きい值 となり,「茶色」,「濃い色」の順に負の大きい值となった。正の值に みられた項目は，木らしい特徴をもつ木材もしくは，重く，白系統 の色のスプルース材に共通した項目であると考えられる。負の值に
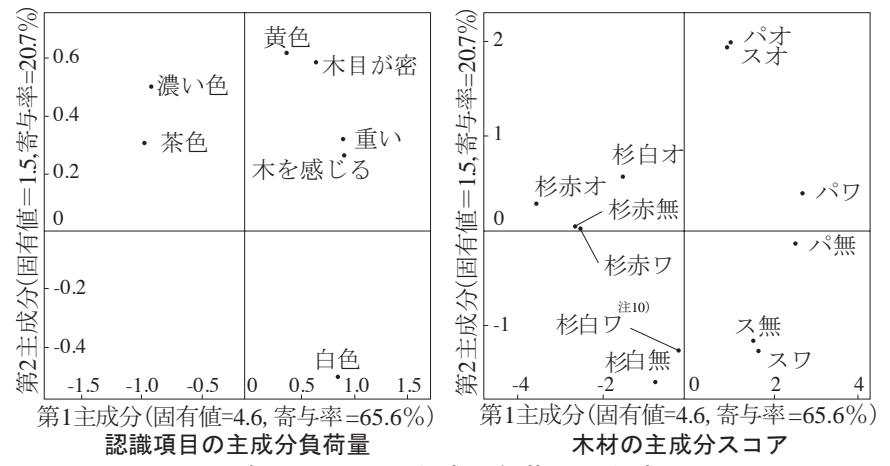

図 5 一般人における主成分負荷量と主成分スコア 
みられた項目は, 茶系統で濃い色をもつ杉赤身材に共通した項目で あると考えられる。これより，第1主成分は，木材のもつ色，木目， 重さなどによる木らしさに関する軸であると位置づけられる。続い て, 第 2 主成分軸の方向において,「黄色」,「木目が密」で主成分負 荷量が正の大きい値となった。また, 負の值では, 「白色」が大きい 值となった。これより,「黄色」はオイル加工が施された木材に共通 した項目であり,「白色」は色味の変化の少ない無垢かワックス加 工が施された木材に共通した項目であると考えられる。よって, 正 の方向で夕られた「木目が密」も考慮すると, 第 2 主成分は色味軸 に加えて，木目の間隔に関する軸と位置づけることができる。

次に, 主成分スコアの散布図をみると, 第 1 主成分軸の方向にお いて, パイン材やスプルース材と杉白太材や杉赤身材が対極に位置 している。一方, 第 2 主成分軸の方向において, オイル加工によっ て黄色味が増した木材に加えて, 無垢材やワックス加工が施された 木材で, 白味の強い木材が対極に位置している。以上の結果から,

一般人における各主成分軸の解釈の妥当性が示された。

\section{3 建築家における主成分負荷量と主成分スコア}

続いて, 建築家における主成分分析の結果を散布図にまとめた（図 6 )。建築家の主成分の寄与率をみると, 一般人と同様に建築家の認 識においても, 第 2 主成分までの累積寄与率が $80.0 \%$ を超えること から，第 $1 ， 2$ 主成分により認識軸の分析を行う。

主成分負荷量の散布図をみると, 第 1 主成分軸の方向において, 「重 い」,「しっとり」,「木目が密」,「白色」の順に正の大きい值となった。 また, 「茶色」,「赤色」,「つるつる」,「木目が面白い」の順に負の大 きい值となった。正の值にみられた項目は, 密な木目で重いパイン 材やスプルース材で, 表面がしっとりとしたオイル加工が施された 木材に共通した項目であると考えられる。また, 負の值にみられた 項目は，杉赤身材かつ無垢材もしくは，ワックス加工が施された木 材に共通した項目であると考えられる。これより, 第 1 主成分軸は, 木材のもつ色, 木目の間隔, 重さなどの特徵に加えて, 表面に加工 が施された木材の表面性状に関わる軸と位置づけられる。続いて, 第 2 主成分軸の方向において, 正の值では, 「塗装」,「黄色」,「つる つる」の順に主成分負荷量が大きい值となった。また, 負の值では, 「濃い色」「「白色」の順に大きい值となった。正の值にみられた項目は, 黄色味が強く, オイル加工のように, 表面の滑らかさが変化する塗 装が施されている木材に共通した項目であると考えられる。さらに, 負の值にみられた項目は, 白色かつ濃い色の木材に共通した項目で あると考えられる。これより, 第 2 主成分軸は, 木材の表面に施さ れた加工の状態に加えて, 色の濃淡に関する軸と位置づけられる。

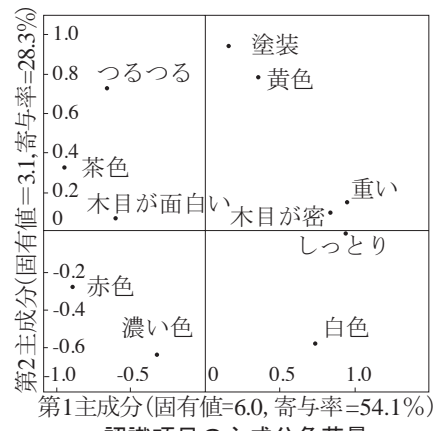

認識項目の主成分負荷量

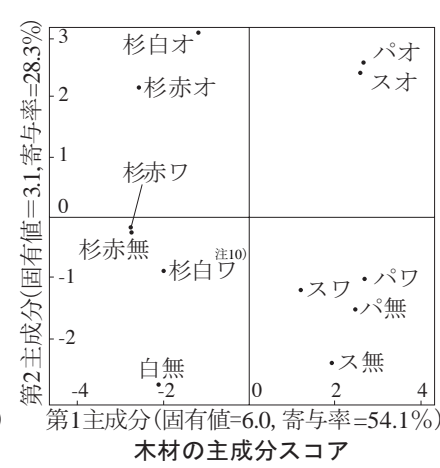

木材の主成分スコア
主成分スコアの散布図をみると，第 1 主成分軸において，建築家も 一般人と同様に，パイン材やスプルース材が杉材と対極に位置してい る。次に, 第 2 主成分軸において, 無垢の木材やワックス加工が施さ れた木材と, オイル加工が施された木材が対極に位置している。以上 の結果から, 建築家における各主成分軸の解釈の妥当性が示された。

\section{4 インテリアデザイナーにおける主成分負荷量と主成分スコア}

インテリアデザイナーにおける主成分分析の結果を散布図にまと めた（図 7 )。インテリアデザイナーの主成分の寄与率をみると, 第 3 主成分までの累積寄与率が $80.0 \%$ を超えることから, 第 1,2 , 3 主成分により認識軸の分析を行う。

主成分負荷量の散布図をみると, 第 1 主成分軸の方向では「重い, 「黄色」,「白色」,「木目が密」,「堅い」の順に正の大きい值となった。 また, 負の値では, 「赤色」,「濃い色」,「茶色」の順に大きい值となっ た。次に, 正の值にみられた項目は, パイン材やスプルース材, 加工 が施された木材に共通する項目であると考えられる。また，負の值に みられた項目は, 杉赤身材やオイル加工が施された木材に共通寸る項 目であると考えられる。これより，第 1 主成分軸は，木材の色味と強 度に関する軸と位置づけられる。続いて, 第 2 主成分軸の方向におい て,「塗装」,「濃い色」,「茶色」で正の大きい值となり,「白色」で負 の大きい值となった。これより，第 2 主成分軸は, 加工による色の濃 淡に関する軸と位置づけることができる。さらに第 3 主成分軸の方向 において,「加工」,「黄色」で正の大きい值であることから, 第 3 主 成分は, 表面の加工と木材の色味に関する軸として位置づけられる。

主成分スコアの散布図をみると, 第 1 主成分軸において, パイン材 やスプルース材と杉材が対極に位置している。また，第 2 主成分軸に おいて, 杉赤身材やオイル加工の木材, 白さの際立つ木材, 無垢材が 対極に位置している。さらに, 第 3 主成分軸において, 杉白太のオイ ル加工材が，他の木材から離れて位置している。以上の結果から，イ ンテリアデザイナーにおける各主成分軸の解釈の妥当性が示された。

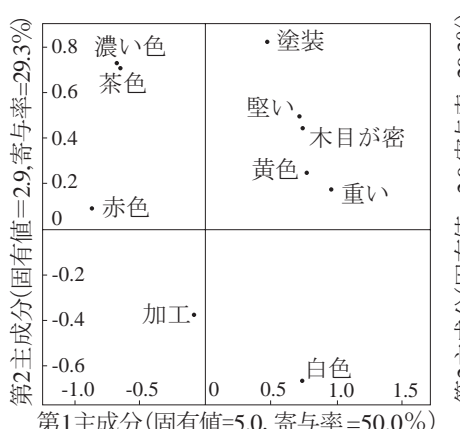

認識項目の主成分負荷量

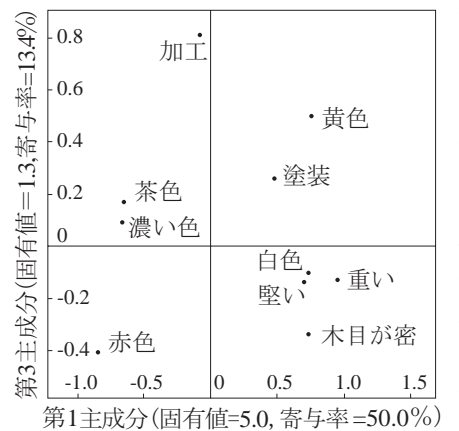

認識項目の主成分負荷量

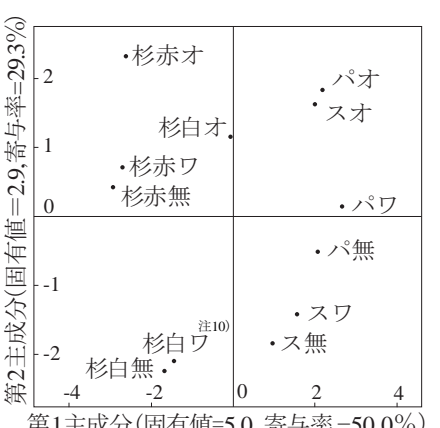

木材の主成分スコア

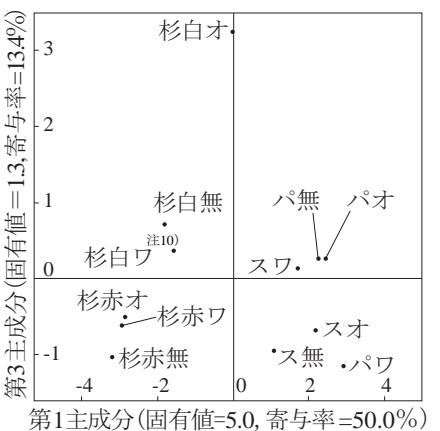

木材の主成分スコア
図 7 インテリアデザイナーにおける主成分負荷量と主成分スコア 


\section{5. 木材に対する選好性と認識項目との相関}

\section{1 被験者の各属性における木材に対する選好性}

続いて，住空間に用いる木材に対する選好性を被験者の属性毎に 分析する。まず，実験に用いた木材について「木材を住空間に用い る際の好ましさ」を基準として, 各被験者が 1 （好まない）～5（好む） の 5 段階評価によって与えた点数を整理した（図 8～1 1)。

学生の選好性（図 8) をみると, 他の属性に比べて全体的なばら つきは小さいが，スワ注11)，杉白才，杉赤才に対する選好性が他の木 材に比べてやや高い結果となった ( $>>0.05) 。 こ の$ 結果から，学生の選 好性では, 統計学的に有意な差はみられなかったが，学生はスワの ように白系統の色で, 木目が密な木材を好む傾向が読みとれる。また, 杉白オや杉赤オのように，オイル加工によって木材の色の濃さが際 立った木材を他の木材よりも好む傾向が読みとれる ${ }^{\text {i土12)。 }}$

一般人の選好性（図 9）をみると，杉赤無，杉赤ワ，杉赤才に対 する選好性が低い結果となった。また，杉赤無に対する選好性とパ ワ，パオに対する選好性において統計学的に有意な差がみられた $(p<0.05) 。 さ ら に ，$ 杉赤ワに対する選好性とパ無，パワ，パ才，ス 無，スオに対する選好性において統計学的に有意な差がみられた $(p<0.05)$ 。これより，一般人は杉赤身材に共通する茶系統で濃い色の 木材を好まない傾向が読みとれる。その一方で，ス無，ス才，パ無， パワ，パオに対する選好性が他の木材に比べて高い結果となった。こ れより, 一般人は加工度合いの少ない木材や, 明るい白系統の色の木 材を好む傾向が読みとれる。また，オイル加工によって黄味が増す ものの，色の濃さが大きく変化しない木材を好む傾向が読みとれる。

建築家の選好性（図 10 ）をみると，学生と同様に全体的なばらつ きは小さいが, 杉白無, 杉白ワ, スワに対する選好性が他の木材に比 べてやや高い結果となった。これより，建築家の木材に対する選好性 では統計学的に有意な差はみられなかった ( $p>0.05)$ が，建築家は広い 木目や濃い白系統の色の木材，スワのように加工度合いが少なく，明 るい白系統の木材を好む傾向が読みとれる。その一方で，パ才，ス才 に対する選好性が低い結果となった。これより，建築家は木目が密で オイル加工によって黄味が増した木材を好まない傾向が読みとれる。

インテリアデザイナーの選好性（図１１）をみると,杉白無, 杉白ワ, 又無に対する選好性が他の木材に比べて高い結果となった。特に, 杉白無に対する選好性とパオ，スオに対する選好性において統計学 的に有意な差がみられ $(p<0.05)$ ， ス無に対する選好性と杉白才，パ オ，スオに対する選好性においても統計学的に有意な差がみられた $(p<0.05)$ 。さらに，杉白ワに対する選好性と杉白オ，パオ，スオに 対する選好性においても, 統計学的に有意な差がみられた $(p<0.05)$ 。 これより，インテリアデザイナーは加工度合いが少ない木材を好む 傾向が読みとれる。これらの傾向は, 統計学的に有意な差はみられ なかったが ( $p>0.05)$ ， パ無，パワ，スワに対する選好性が比較的高 いことからも読みとれる。その一方で，杉白才，パオ，スオに対す る選好性は，他の木材と比べて全体的に低い結果となった。これよ り，インテリアデザイナーは，オイル加工によって色の濃さや黄色 味が増した木材を好まない傾向が読みとれる。さらに，統計学的に 有意な差はみられなかった $(p>0.05)$ が，杉赤無，杉赤ワ，杉赤オの 選好性において，ばらつきがみられるものの，全体的に低い結果と なった。これより，インテリアデザイナーは，杉赤身材のように， 濃い茶系統の色で木目の広い木材を好まない傾向が読みとれる注13)。

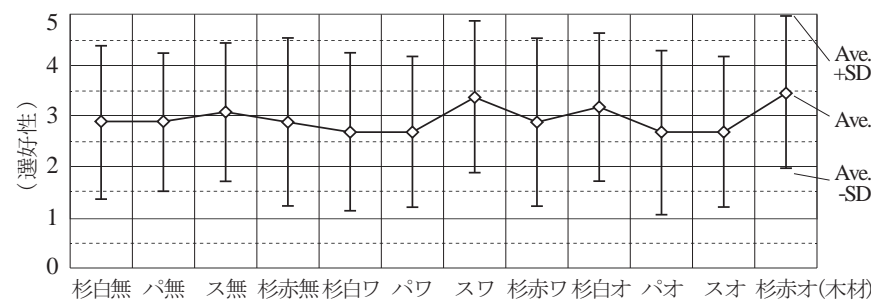

図 8 学生における各木材に対する選好性
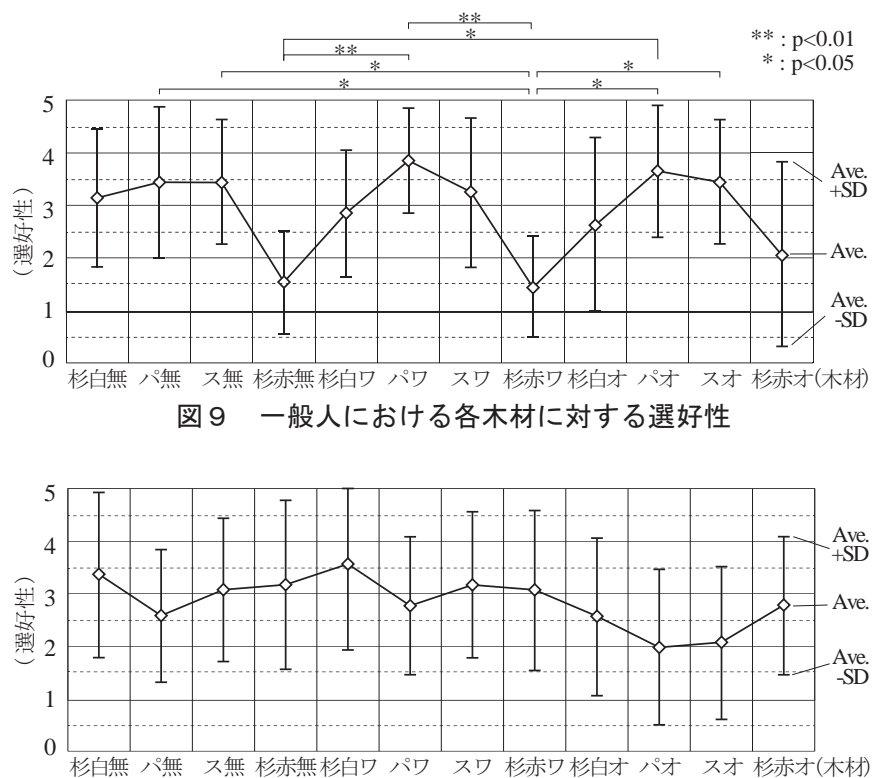

図 10 建築家における各木材に対する選好性

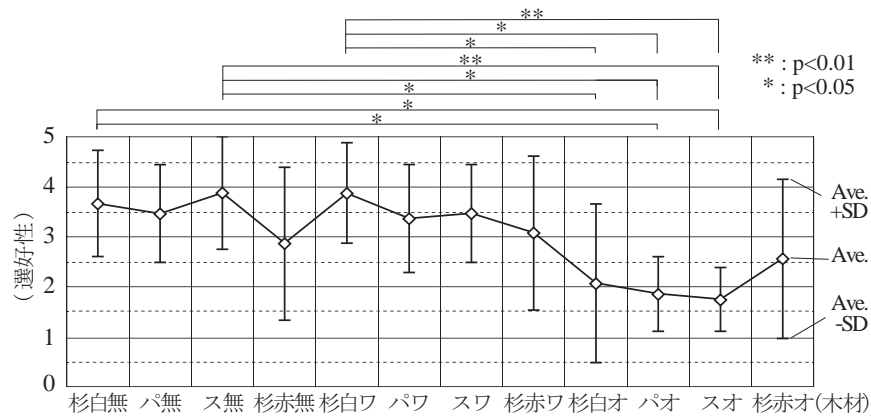

図１１インテリアデザイナーにおける各木材に対する選好性

\section{2 選好性と認識項目の相関関係}

次に，被験者の各属性における木材に対する選好性と認識項目に よる相関分析を行う。さらに，被験者の各属性において，選好性と 有意な相関関係 $(p<0.05)$ をもつ項目に着目寸ることで，木材に対す る選好性と認識項目の関係性を考察する（表 $5 \sim 8$ )。

学生における相関分析を行った結果（表 5 ）をみると,「つるつる」 が最も高い正の相関 $(p>0.05)$ を示し,「黄色」が最も高い負の相関 $(p>0.05)$ を示した。これより, 有意な相関を示寸項目はみられなかっ たが，学生は表面が滑らかな木材を好み，黄色味の強い木材を好ま ない傾向が読みとれる。その一方で, 学生の木材に対する認識では, 多くの認識項目が指摘されているにも関わらず，選好性と有意な相関 をもつ項目がみられない。これより，学生は木材を多角的に認識して いるが，木材に対する選好性は特定の認識項目によらず，多くの項 目が複合的に関与して形成されていることを示唆しているといえる。 
表 5 学生における認識項目と選好性の相関

\begin{tabular}{|c|c|c|c|c|c|}
\hline 認識項目 & 相関係数 & $\mathrm{p}$ 值 & 認識項目 & 相関係数 & $\mathrm{p}$ 值 \\
\hline つるつる & 0.494 & 0.102 & 黄色 & -0.465 & 0.128 \\
\hline 茶色 & 0.284 & 0.370 & でこぼこがある & -0.397 & 0.202 \\
\hline 木目がきれい & 0.236 & 0.460 & 木目が密 & -0.346 & 0.270 \\
\hline 時間が経っている & 0.178 & 0.995 & 重い & -0.267 & 0.401 \\
\hline \multirow{4}{*}{\multicolumn{3}{|c|}{$\begin{array}{l}\text { ※左側に正の相関係数をもつ項目, 右側 } \\
\text { に負の相関倸数をもつ項目を表示した。 }\end{array}$}} & 濃い色 & -0.138 & 0.670 \\
\hline & & & 新鮮な & -0.071 & 0.826 \\
\hline & & & 明るい色 & -0.041 & 0.899 \\
\hline & & & シンメトリー & -0.021 & 0.947 \\
\hline
\end{tabular}

表 6 一般人における認識項目と選好性の相関

\begin{tabular}{|c|c|c|c|c|c|}
\hline 認識項目 & 相関係数 & $\mathrm{p}$ 值 & 認識項目 & 相関係数 & $\mathrm{p}$ 值 \\
\hline 木を感じる & 0.856 & $0.000^{* *}$ & 茶色 & -0.856 & $0.000^{* *}$ \\
\hline 重い & 0.810 & $0.001^{* *}$ & 濃い色 & -0.775 & $0.003^{* *}$ \\
\hline 白色 & 0.730 & $0.007^{* *}$ & \multirow{3}{*}{\multicolumn{3}{|c|}{$\begin{array}{r}\text { ※左側に正の相関係数をもつ項目, 右側 } \\
\text { に負の相関係数をもつ項目を表示した。 } \\
* *: p<0.01, *: p<0.05\end{array}$}} \\
\hline 黄色 & 0.561 & 0.058 & & & \\
\hline 木目が密 & 0.533 & 0.075 & & & \\
\hline
\end{tabular}

\section{表 7 建築家における認識項目と選好性の相関}

\begin{tabular}{|c|c|c|c|c|c|}
\hline 認識項目 & 相関係数 & $\mathrm{p}$ 值 & 認識項目 & 相関係数 & $\mathrm{p}$ 值 \\
\hline 濃い色 & 0.678 & $0.015^{*}$ & 黄色 & -0.883 & $0.000^{* *}$ \\
\hline 赤色 & 0.653 & $0.021^{*}$ & 塗装 & -0.820 & $0.001^{* *}$ \\
\hline 木目が面白い & 0.447 & 0.145 & 重い & -0.718 & $0.009^{* *}$ \\
\hline 茶色 & 0.170 & 0.598 & 木目が密 & -0.698 & $0.012^{*}$ \\
\hline 白色 & 0.105 & 0.746 & しっとり & -0.498 & 0.099 \\
\hline \multicolumn{3}{|c|}{ ※左側に正の相関係数をもつ項目, 右側 } & つるつる & -0.069 & 0.831 \\
\hline
\end{tabular}

表 8 インテリアデザイナーにおける認識項目と選好性の相関

\begin{tabular}{|c|c|c|c|c|c|}
\hline 認識項目 & 相関係数 & $\mathrm{p}$ 值 & 認識項目 & 相関係数 & $\mathrm{p}$ 值 \\
\hline 白色 & 0.513 & 0.088 & 塗装 & -0.835 & $0.000^{* *}$ \\
\hline 加工 & 0.254 & 0.426 & 茶色 & -0.619 & $0.032^{*}$ \\
\hline 赤色 & 0.200 & 0.533 & 濃い色 & -0.600 & $0.039 *$ \\
\hline \multirow{2}{*}{\multicolumn{3}{|c|}{$\begin{array}{l}\text { ※左側に正の相関係数をもつ項目, 右側 } \\
\text { に負の相関係数をもつ項目を表示した。 }\end{array}$}} & 黄色 & -0.524 & 0.081 \\
\hline & & & 堅い & -0.438 & 0.154 \\
\hline \multirow{2}{*}{\multicolumn{3}{|c|}{$* *: p<0.01, *: p<0.05$}} & 木目が密 & -0.404 & 0.192 \\
\hline & & & 重い & -0.231 & 0.470 \\
\hline
\end{tabular}

一般人における相関分析を行った結果（表 6 ）をみると，「木を感 じる」,「重い」,「白色」が有意な正の相関 $(p<0.05)$ を示し, 「茶色」, 「濃い色」が有意な負の相関（ $p<0.05 ）$ を示した。これより，一般人 では, 木らしい特徴, 密な木目や重さといった特徴が選好性と結び ついていることが読みとれる。また，「木を感じる」，「重い」，「白色」 はパイン材やスプルース材に共通した特徵であり,「茶色」,「濃い色」 は杉赤身材に共通した特徴を示しているといえる。以上より，一般 人はパイン材やスプルース材の中でも, 特に無垢材やワックス加工 などの自然の状態に近い木材を好む一方で，杉赤身材を好まない傾 向が示唆された。これらの傾向は, 前節において, 無垢材やワック ス加工材に対する点数が他の木材に比べて高く，杉赤身材に対する 点数が全体的に低い結果とも一致する。

建築家における相関分析を行った結果（表 7 ）をみると,「濃い色」, 「赤色」が有意な正の相関（ $p<0.05 ）$ を示した。これより, 建築家では, 赤系統の色や濃い色といった特徵が選好性と結びついていることが読 みとれる。また, 「濃い色」,「赤色」は，杉赤身材に共通した特徵を 示しているといえる。一方で, 有意な負の相関（ $p<0.05 ）$ を示した「黄 色」,「塗装」,「重い」, 「木目が密」は, パイン材やスプルース材に共
通した特徴であり, 特にこれらの木材にオイル加工が施された際の特 徵を示しているといえる。以上より, 建築家は杉赤身材を好み, 特に オイル加工が施されたパイン材やスプルース材を好まない傾向が示唆 された。これらの傾向は，前節において，杉赤身材に対する点数や無 垢材，ワックス加工材に対する点数が全体的に高いが，オイル加工が 施された木材に対する点数が低い結果とも一致する。

インテリアデザイナーにおける相関分析を行った結果（表 8 ）をみ ると,「白色」が比較的高い正の相関 ( $p>0.05)$ を示し, 「塗装」,「茶色」, 「濃い色」が有意な負の相関 $(p<0.05)$ を示した。これより，有意な 正の相関を示寸特定の項目はみられなかったが，有意な負の相関を示 した項目から，インテリアデザイナーは加工の中でも，特にオイル加 工が施され，茶系統で濃い色の木材を好まない傾向が読みとれる。ま た, 「塗装」,「茶色」,「濃い色」は，杉赤身材もしくは，オイル加工 が施された木材の特徴を示しているといえる。以上より，インテリア デザイナーは，茶系統かつ濃い色をもつ杉赤身材もしくは，オイル加 工によって色の濃さが増した木材を好まない傾向が示唆された。これ らの傾向は，前節において，杉赤身材やオイル加工が施された木材に 対する点数が全体的に低い結果とも一致する。

\section{6. 認知構造からみる潜在的選択要因}

前章までの主成分分析に基づく主成分負荷量，主成分スコア，木 材に対する選好性, 認識項目と選好性の相関分析の結果から, 被験 者各属性の木材に対する認識や選好性の傾向を得ることができた。 そこで本章では，それらの傾向を整理し重㸚合せることで，木材を 空間に用いる際の潜在的選択要因を考察する（図 12 ）。なお，潜在 的選択要因 $A \sim$ J は認識軸を構成する各主成分に関わる項目と選好 性との相関をもつ項目の両側面を考慮して決定した。

学生において, A は木材の色の明暗, 重さ, 木目の間隔, 表面性状, 時間変化や新鮮さなどの木材から受ける印象に関わる項目によって 構成されることから，A は無垢やワックス加工が施された木材がもつ 色や木目による，木材の新鮮さや経年変化を表している。B は茶色や 黄色といった色味に関する項目と木材の重さに関する項目によって 構成されることから，B は木材の色味と重さを表している。Cは木材 のもつ色の濃さ，木目の間隔と形状に関わる項目によって構成される ことから，Cは色の濃淡と木目の間隔と対称性を表している。

一般人において，D は木材の色味，木目の間隔，重さ，木らしさ などに関わる項目によって構成される。これらの項目のうち,「白色」 $(r=0.730)$,「木を感じる」 $(r=0.856)$, 「重い」 $(r=0.810)$ が選好性と 有意な正の相関を示し,「茶色」 $(r=-0.856)$,「濃い色」 $(r=-0.775)$ が 選好性と有意な負の相関を示した。以上より，D はスプルース材の ように白色の木材で, 密な木目や重さなどによる木らしい印象を表 している。E は木材のもつ色味や濃淡，木目の間隔，重さに関わる 項目によって構成され, これらの項目のうち,「白色」,「重い」が有 意な正の相関を示し,「茶色」と「濃い色」が有意な負の相関を示した。 以上より, E は木材のもつ色味, 色の濃淡, 重さを表している。

建築家において, F は木材のもつ色味, 木目の間隔と印象, 重さ, 表面状態など幅広い項目によって構成される。これらの項目のうち, 「赤色」 $(r=0.653), 「$ 濃い色」 $(r=0.678)$ が選好性と有意な正の相関を 示し, 「黄色」 $(r=-0.883)$,「木目が密」 $(r=-0.698)$, 「重い」 $(r=-0.718)$ が有意な負の相関を示した。以上より，F は日本産の杉赤身材など濃 
い赤系統の色と木目への馴染みと表面性状を表している。G は木材の 色味と濃淡，木目の間隔，塗装に関寸る項目によって構成され，これ らの項目のうち, 「濃い色」が有意な正の相関を示し,「木目が密」,「黄 色」,「重い」,「塗装」( $\mathrm{r}=-0.820)$ が有意な負の相関を示した。以上よ り, G は木材の色の濃淡に加えて, 重さや塗装度合いを表している。

インテリアデザイナーにおいて, H は木材の色味と濃淡, 木目の 間隔, 重さ, 堅さに関する項目によって構成される。これらの項目 のうち,「茶色」( $r=-0.619)$, 「濃い色」( $r=-0.600)$ が有意な負の相関 を示した。以上より, H は木材の色味に加えて, 重さや堅さを表し ている。।は木材の色味と濃淡に加えて, 塗装に関わる項目によって 構成される。これらの項目のうち, 「茶色」, 「濃い色」, 「塗装」( $\mathrm{r}=-0.835)$ が有意な負の相関を示した。以上より，।は加工の少なさによる色の 濃淡や色味を表している。」は木材の色と加工に関わる項目によって 構成され,これらの項目のうち,「濃い色」が有意な負の相関を示した。 以上より, 」は加工された木材のもつ色の濃淡を表している。

各属性の潜在的選択要因における特徴として, 学生では「新鮮な」 や「時間が経っている」のように，木材の経年変化に関する項目が みられたことから, 学生は色などの特徵が大きく変化しない人工材 に比べて, 変化の割合が大きい自然な木材の時間的な変化に着目し て木材を選択していることが読みとれる。また，学生では，有意な 相関を示した項目はみられないが，多様な認識項目によって木材を 選択していると考えられる。その一方で，一般人では「木を感じる」 のように，色，木目，重さなどによる木材の「木らしさ」に関する 項目がみられたことから，一般人は自然素材としての木らしさに着 目して木材を選択していることが読みとれる。

建築家では「赤色」,「濃い色」で有意な相関がみられたことから, 建築家は設計する空間をイメージしながらも, 馴染みによって木材 を選択していることが読みとれる。また,インテリアデザイナーでは，
「塗装」,「茶色」,「濃い色」で有意な相関がみられたことから，木材 の色を重視する一方で, インテリアデザイナーは塗装や人工的な加 工による色の変化により着目していることが読みとれる。これら木 材の変化に対寸る傾向は，建築家において「しっとり」や「塗装」 がみられることからも，専門家に共通した特徴であると考えられる。

\section{7. 結論}

被験者における各属性の内装用木材に対する認識傾向の特徵とし て, 非専門家である学生や一般人は, 木材の色や木目などの特徵を 中心に木材を認識していた。その一方で, 専門家である建築家やイ ンテリアデザイナーは非専門家と同様に, 木材の視覚的な情報に加 えて，木材表面の状態や加工度合いなどの物性的な特徵にも着目し て，より多角的に木材を認識していることが明らかとなった。

また, 木材に対する選好性では, 学生や一般人は, 専門家に比べ てオイル加工が施された木材に対寸る選好性が高い傾向がみられた。 また, 建築家とインテリアデザイナーでは, 非専門家とは対照的に, 無垢材やワックス加工材に対する選好性が高い傾向がみられた。特 に, 建築家は木材に施される加工の少なさを重視し, 一方, インテ リアデザイナーは加工による木材のもつ色合いの変化を重視してい る点に専門家における違いもみられた。

さらに, 潜在的選択要因の特徵として, 各属性において木材の物性 的な特徵に関する項目が共通してみられた。その中でも，学生は木 材の時間経過による特徵の変化にも着目しており, 一般人は自然素 材として木材がもつ木らしさも重視していることが明らかとなった。 また，建築家は木材に施される加工による変化や木材に対する馴染 みも重視しており, インテリアデザイナーは白系統の色を基本とし て, 黄色や赤色などの色に関する特徴や, 加工によってもたらされ る色の繊細な違いにも着目していることが明らかとなった。

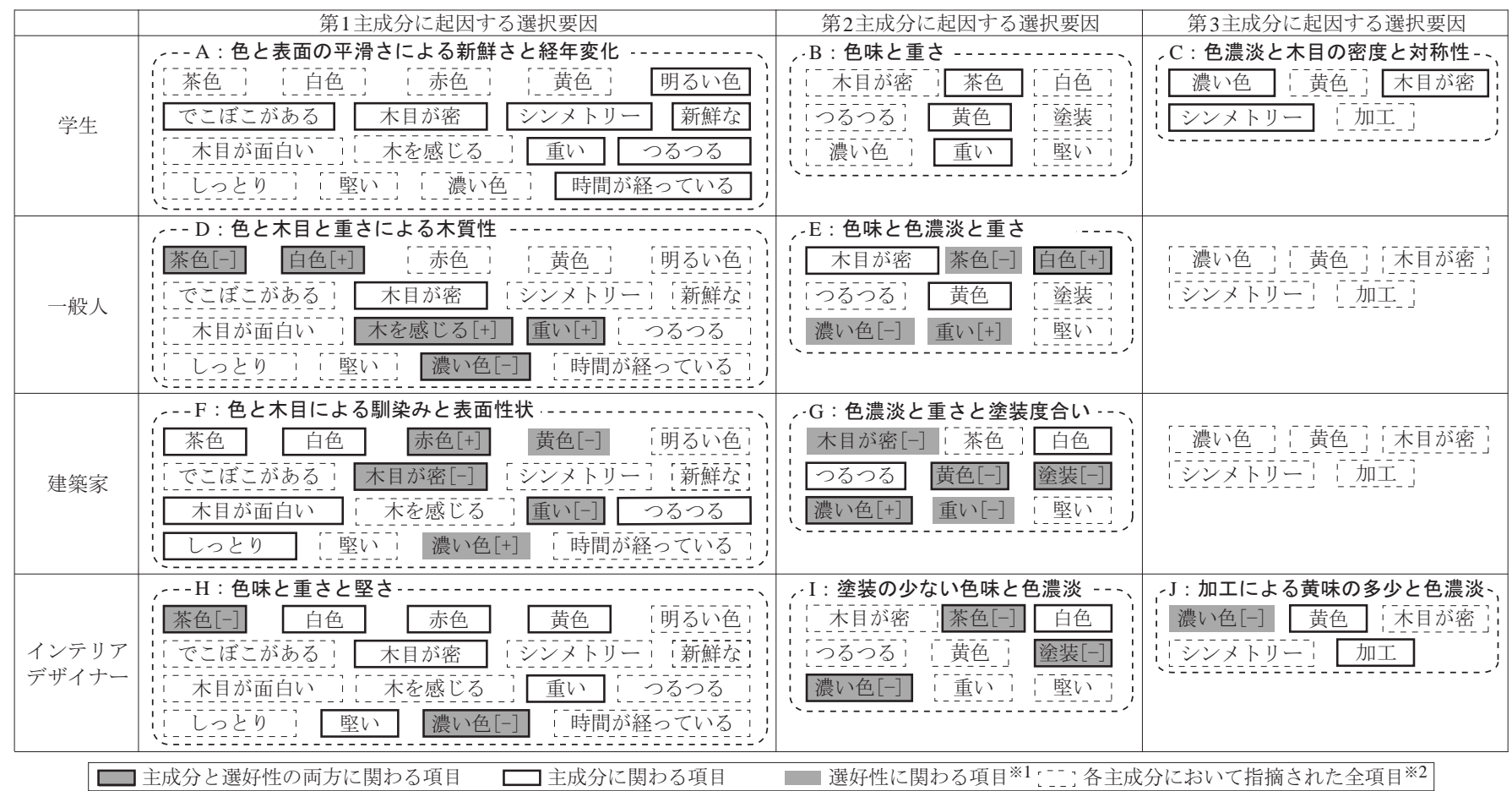




\section{謝辞}

日本の建築家，インテリアデザイナー，一般人，学生の方々には， 限られた時間の中で個別インタビューにご参加頂き, 論文を進める 上で多大な御協力を頂きました。また，須藤美音准教授（名古屋工 業大学大学院工学研究科) には, 統計解析の観点から大変有益なご 助言を頂きました。また, 柴田智菜美氏（名古屋工業大学大学院工 学研究科博士前期課程), 長谷川明香氏 (名古屋工業大学大学院工学 研究科博士前期課程）には, 資料, 論文作成において多大な御協力 を頂きました。文末になりますが，ここに記して感謝申し上げます。

\section{注}

注 1）学生及び一般人は，建築，インテリア，木材に関連する分野を専攻又 は専門としていない者とした。

注 2）、材サンプルの大きさは，W $100 \mathrm{~mm} \times \mathrm{H} 250 \mathrm{~mm} \times \mathrm{D} 10 \mathrm{~mm}$ である。これ らの木材の大きさは，木材の色や木目などの個体差が被験者に影響を 及ぼす点を考慮し，全ての被験者が容易に手にとり，視覚，触覚，嗅 覚など様々な観点から, 各木材のもつ特徴を十分観察することが可能 となるよう配慮して決定した。また，木材は無節で，模様，色，コン トラストなどを考慮して選定されたものを使用している。さらに，全 ての木材を室温 20 度, 湿度 $65 \%$ の環境下で一定期間保管し，含水率な どの前提条件を揃えた上で個別のインタビューに使用した。なお，本稿 で用いたワックスやオイルは一般的に流通している自然由来のもので あり, ワックスはLIBERON 社のBIVAX MEHILÄISVAHA (NEUTRAL), オイルは LE TONKINOIS 社の Bio Impression を採用し, 木材の表面にム ラが出ないよう均一に塗布した（カラー写真は既稿引を参照）。

注 3) 本稿でも「3 個組技法」を用いた理由として, 人の認知は, 一般的に 経験や周辺環境など様々な要因から影響を受け, 多種多様な認知の構 造が存在すると考えられる。そこで, 従来の評定尺度法などのように, あらかじめ評価尺度を設定せず, 各被験者のもつ個人差や認知の多様 性を尊重した上で選択要因の把握を試みるため, 被験者自身の言葉で 着眼点を抽出することが可能な方法として,「了個組技法」を用いた。 なお，3 個組技法によるインタビューを行う際，各木材の組合せは同 樹種，同加工の木材が同じ組に含まれないようにし，全体で各木材が 3 回ずつ含まれるように木材の組合せと順序を決定した（表 9)。

注 4）例として, 認識項目の一つである「明るい色」では,「より明るい」と 感じる場合に 5 点, 逆に「より暗い」と感じる場合に 1 点, 「普通」と 感じる場合は 3 点といったように, 各項目によって木材毎に $1 \sim 5$ 点 で点数を与えるように指示した。なお，「明るい色」と「暗い色」のよ うに，逆の意味を示す項目が存在する場合でも，各被験者が各木材に 点数を与える時点では被験者が指摘した項目をそのまま用いた。ただ し，統計分析を行う上で，「暗い色」一「明るい色」という一つの評価 尺度として扱うため,「暗い」が 1 点, 「やや暗い」が 2 点, 「普通の明 るさ」が 3 点, 「やや明るい」が 4 点, 「明るい」が 5 点となるよう,「暗 い色」の点数を変換して点数及び指摘回数の集計を行った。

注 5）住空間，オフィス空間，商業空間，公共空間など多種多様な建築物の 用途のうち, 本稿においても，住宅や集合住宅などの居住に関わる「住 空間」を対象とした。また，被験者のイメージする一般的な住空間を 対象に分析を行うため, 特定の室機能や用途の制限を設けず, 各被験 者に自分自身にとっての「住空間」をイメージするように指示した。

注 6) 3 名の著者によって, 意味内容の類似性をもとに各項目を統一し，分 類作業を行った。続いて, 項目を意味内容によってまとめることで小

表 9 インタビューに用いた木材の組合せ

\begin{tabular}{|c|c|c|c|c|c|c|c|c|c|c|c|c|}
\hline 組 & 杉白無 & パ無 & 又無 & 杉赤無 & 杉白ワ & パワ & スワ & 杉赤才 & 杉白才 & パオ & 犲 & 杉赤才 \\
\hline 1 & 0 & & & & & 0 & & & & & 0 & \\
\hline 2 & & & 0 & & 0 & & & & & 0 & & \\
\hline 3 & & 0 & & & & & 0 & & & & & 0 \\
\hline 4 & & & & 0 & & & 0 & & 0 & & & \\
\hline 5 & & 0 & & & 0 & & & & & & 0 & \\
\hline 6 & 0 & & & & & & & 0 & & 0 & & \\
\hline 7 & & & 0 & & & 0 & & & & & & 0 \\
\hline 8 & & & & 0 & 0 & & & & & 0 & & \\
\hline 9 & & & 0 & & & & & 0 & 0 & & & \\
\hline 10 & 0 & & & & & & 0 & & & & & 0 \\
\hline 11 & & & & 0 & & 0 & & & & & 0 & \\
\hline 12 & & 0 & & & & & & 0 & 0 & & & \\
\hline
\end{tabular}

分類を，各小分類を包括するグループによってまとめることで大分類 を得た。各項目の最終的な分類は, 大分類と小分類によって決定される。

注 7）被験者の各属性における指摘回数の平均值と標準偏差は, 専門家の建 築家では, 11.2 22.66, インテリアデザイナーでは, $11.9 \pm 6.77$ であった。

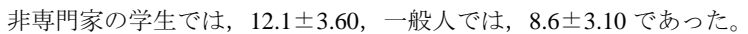

注 8）本稿の個別インタビューにおける全認識項目とその指摘回数を, 表 4 の発言例を含めた一覧としてまとめた（表 10 ，表 11 ）。

\section{表 10 専門家の認識項目の分類と指摘回数}

\begin{tabular}{|c|c|c|}
\hline & & \\
\hline 大分類 & 小分類 & 認識項目とその指摘回数(建築家/インテリアデザイナー) \\
\hline & $\{$ 色相 $\}$ & 黄色(7/6),茶色(3/4), 白色(11/5), 赤色(6/3),肌色(2/0), オレンジ(1/0), 黒・白(0/1) \\
\hline & $\{$ 明度 $\}$ & 明るい色(0/1) \\
\hline & $\{$ 濃度 $\}$ & 濃い色(4/4) \\
\hline 【色】 & 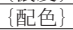 & \\
\hline & \{印象\} & $\begin{array}{l}\text { 人工色(3/2), キャラクターのある色(1/0),使う場所を選ぶ色(0/1), 有色(2/1), } \\
\text { 無地な色 }(0 / 1), \text { 馿染みのある色(0/1), その他の色 }(0 / 1) \text {, 自然色(2/0) }\end{array}$ \\
\hline & \{形状\} & 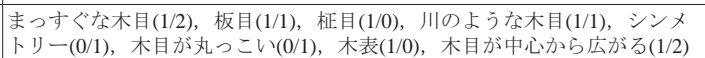 \\
\hline & $\{$ 密度 $\}$ & 木目が密(7/3) \\
\hline 【模様】 & $\{$ 明瞭 $\}$ & 木目のコントラストが強い(2/3) \\
\hline & $\left\{\mathrm{F}^{2}\right.$ 象\} & $\begin{array}{l}\text { 木目が面白い }(3 / 0), \text { 木目が似ている(1/0), 木目がうっとうしい(1/0), 木目 } \\
\text { が和風(1/0), 木目がばらばら(1/0), 木目が好み(0/1) }\end{array}$ \\
\hline & \{価值 $\}$ & 木目が美しい(1/0) \\
\hline & $\{$ 加工 $\}$ & 加工(2/3)，素地(2/3)，塗装(3/4) \\
\hline & $\{$ 光沢\} & 光沢(0/1) \\
\hline 【表面】 & \{平滑\} & つるつる(4/0), でこぼこがある(1/0) \\
\hline & $\{$ 污れ・傷\} & 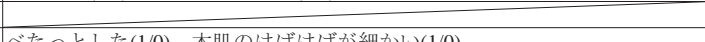 \\
\hline 【香気】 & 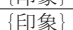 & 人工的なにおい(0/1) \\
\hline & $\{$ 重量\} & 重い(6/5), 素材が密(2/1) \\
\hline & $\{$ 強度 $\}$ & 堅い(1/5) \\
\hline & $\{$ 汎用 $\}$ & 空間を選ぶ(1/0), 適応できる(1/0),使いやすい(0/1) \\
\hline 【特質】 & \{用途\} & $\begin{array}{l}\text { 壁に使う(0/1), レストラン }(0 / 1), \text { 旅館(0/1), 山荘(0/1), 素足の空間(0/1), } \\
\text { 丁寧な空間(0/1), 小さな空間 }(0 / 1), \text { 床に使う(0/2) }\end{array}$ \\
\hline & $\{$ 品質 $\}$ & \\
\hline & $\{$ 産地 $\}$ & 外国产(1/0) \\
\hline & $\{$ 樹種\} & 松(1/0)，杉(1/1)，立木が大きい樹種(1/0)，成長の早い樹種(0/1) \\
\hline & $\{$ 乾燥\} & しっとり $(4 / 0)$ \\
\hline 【心象】 & $\{$ 印象\} & 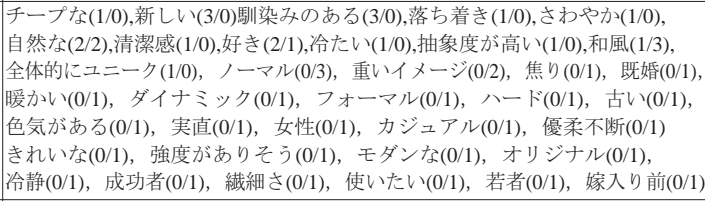 \\
\hline & $\{$ 価値 $\}$ & 魅力のある(0/1) \\
\hline
\end{tabular}

表 11 非専門家の認識項目の分類と指摘回数 認識項目とその指摘回数(学生/一般人)

\begin{tabular}{|c|c|c|}
\hline 大分類 & 小分類 & 認識項目とその指摘回数(学生/一般人) \\
\hline \multirow{5}{*}{ 【色】 } & $\{$ 色相 $\}$ & 黄色(5/4),茶色(6/7),白色(3/4),赤色(1/0), 肌色(0/1) \\
\hline & $\{$ 明度 $\}$ & 明るい色(5/2) \\
\hline & $\{$ 濃度\} & 濃い色(8/6) \\
\hline & $\{$ 配色\} & 色が並べたときにきれい(1/0) \\
\hline & \{印象\} & 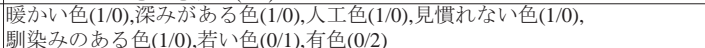 \\
\hline \multirow{5}{*}{ 【模様】 } & $\{$ 形状\} & $\begin{array}{l}\text { 木目がくねくね(2/0), 木目が丸っこい(1/2), まっすぐな木目 }(1 / 1), \text { シンメ } \\
\text { リリー(3/0), 中心の木目が歪んでいる(1/0), 太い木目が目立つ(0/1), 真ん中 } \\
\text { に大きな木目 }(0 / 2), \text { 三角の模様 }(0 / 2)\end{array}$ \\
\hline & $\{$ 密度 $\}$ & 木目が広い(1/1)，木目が密(11/8),規則的な木目(0/1) \\
\hline & $\{$ 明膫 $\}$ & 木目のコントラストが強い(3/1) \\
\hline & $\{$ 印象\} & 木目がきれい $(4 / 1)$,バームクーヘンのような年輪 $(1 / 0)$ ，中心に線が入っている(1/0) \\
\hline & $\{$ 価値 $\}$ & \\
\hline \multirow{5}{*}{ 【表面】 } & $\{$ 加工 $\}$ & 加工(2/1) \\
\hline & $\{$ 光沢 $\}$ & 光沢(2/2) \\
\hline & $\{$ 平滑 $\}$ & つるつる(7/6)，でこぼこがある(4/0),触り心地が油っぽい(1/0) \\
\hline & 洿机・傷\} & 傷が目立つ(1/0) \\
\hline & $\{$ 印象 & 触った感じが気持ちいい(1/0)，触って抵抗を感じない(1/0)，手触りが好き(1/ \\
\hline 【香気】 & 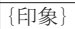 & 自然らしいにおい $(1 / 0)$ \\
\hline \multirow{8}{*}{ 【特質】 } & \{重量\} & 重い(10/8) \\
\hline & $\{$ 強度 $\}$ & 堅い(2/0), 反れそう(1/0) \\
\hline & $\{$ 汎用 $\}$ & \\
\hline & \{用途\} & $\begin{array}{l}\text { 学校の机にありそう(1/0), 頻繁に動かすものに使ってほしい(1/0), } \\
\text { まな板みたいな(1/0),新築のイメージ(1/0),作ってる途中の家(0/1), } \\
\text { おじいちゃんの家のイメジ }(1 / 0), \text { 自宅の床っぽい(0/1) }\end{array}$ \\
\hline & \{品質\} & $\begin{array}{l}\text { 状態が良い(1/0),安定感がある(0/2),不揃いな木材(0/1),頼りない(0/2), } \\
\text { きれいに切った木材 }(0 / 1)\end{array}$ \\
\hline & $\{$ 产地 $\}$ & 外国産(1/0) \\
\hline & $\{$ 樹種\} & 細い樹種(1/0)，まっすぐ育った樹種(1/0) \\
\hline & $\{$ 乾燥 $\}$ & 乾燥した(1/0)，水分が抜けていそう(1/0),叨いた音が高い(1/0) \\
\hline \multirow[t]{2}{*}{ 【心象】 } & $\{$ 印象 $\}$ & 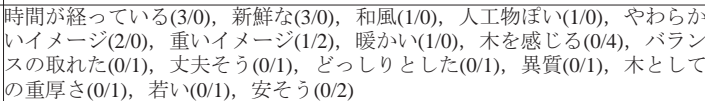 \\
\hline & $\{$ 価值 $\}$ & \\
\hline
\end{tabular}


注 9）コレスポンデンス分析は, クロス集計表における表頭項目と表側項目 の相関関係が最大になるように，行と列を並び替えて数量化する手法 である ${ }^{6)}$ 。一般的には，初めに数值化されたものがクロス集計表の結 果をより強く反映しており，本稿では 1 つ目の数值化の結果を横軸に, 2つ目の結果を縦軸として散布図を作成して分析に用いた。なお，3.2 節以降において, 各属性の分析や考察を行う際, 特に断りのない限り, 学生, 一般, 建築家, インテリアデザイナーの順に結果を記載する。

注 10) 図 4〜 7 における各木材のサンプルスコアに記載されている略称は, 各木材の樹種と加工の種類を示している。例として「杉白ワ」は，杉 白太のワックス加工材を示している。

注 11） 各木材の略称は，木材の樹種と加工の種類を示す。

注 12）オイル加工が各木材の特徴にもたらす変化における違いとして，杉白 太材及び赤身材では，オイル加工によって表面の艶が生まれ，色の明 瞭さや濃さが変化する。それに対して, パイン材やスプルース材では, 杉材と同様に才イル加工によって表面に艶が生まれ，黄色味が増すも のの, 色の濃さは大きく変化しない。

注 13）杉赤身材は元々の色が濃く, 赤茶系統の色であるため, オイル加工を 施した際の色の変化が少ないことから，オイル加工が施された木材の 中では, 選好性が比較的高い結果になったと考えられる。

\section{参考文献}

1）林野庁：平成 26 年版森林・林業白書, 2014.6

2）坂口大史，柴田智菜美，坂井文也，北川啓介：内装用木材の認知構造から みる潜在的選択要因，フィンランドの設計専門家と非専門家を対象とし て，日本建築学会計画系論文集，第 715 号，pp.2021-2031，2015.9

3）坂口大史，坂井文也，北川啓介：日本の設計専門家と非専門家の住空間に 用いる内装用木材に対する評価構造，日本建築学会計画系論文集，第 721 号，pp.581-591, 2016.3

4) J ussi Tiainen, Wood A rchitecture in Finland, Rakennustieto Publishing, 2008.3

5) Kuismanen Kimo, INNOVATIVE USE OF WOOD IN ARCHITECTURE, Oulu 2013.5

6）内田治：すぐわかるSPSSによるアンケートのコレスポンデンス分析，東 京図書 , 2006.10 


\title{
LATENT SELECTIVE FACTOR OF JAPANESE DESIGN PROFESSIONALS AND LAYMEN THROUGH ANALYSIS OF COGNITIVE STRUCTURE OF WOOD FOR INTERIOR
}

\author{
Daishi SAKAGUCHI* , Fumiya SAKAI ${ }^{* *}$ and Keisuke KITAGAWA *** \\ * Doctoral Candidate, Graduate School of Engineering, Nagoya Institute of Technology: \\ Assist. Prof., Faculty of Health Science, Nihon Fukushi Univ., Master of Engineering \\ ** Kisogawa-Joryu River Office, Chubu Regional Bureau, Ministry of Land, Infrastructure and Transport, Master of Engineering \\ *** Assoc. Prof., Tsukuri College, Graduate School of Engineering, Nagoya Institute of Technology, Doctor of Engineering

\section{Introduction}

In the previous study, the latent selective factor of Finnish design professionals and laymen when choosing wood for living space was revealed through the analysis on the cognitive structure of wood for interior. Following the study, this paper aims to clarify the latent selective factor of Japanese design professionals and laymen.

\section{Material \& Method}

As in the previous study, this study also included 12 different wood samples (4 different species: Finnish spruce: Picea abies, Finnish pine: Pinus sylvestris, and heartwood and sapwood of Japanese cedar: Cryptomeria japonica and 3 different finishing: plain surface, wax coating and oil finishing). 40 participants (10 people each from architect, interior designer, normal worker and student) were interviewed. The data was analyzed using principal component analysis (PCA) and correlation analysis to grasp the relationship between the cognitive elements and the preference.

\section{Result \& Discussion}

From the result of the interview, 6 core categories and 26 detailed categories were extracted as the cognitive elements. These elements were analyzed by PCA. According to the results from PCA, both professionals and laymen basically recognized wood from the physical features such as tone, light and shade of color, shape and interval of grain, surface condition and weight.

As for the preference of wood for living space, the preference between professionals and laymen except normal workers was not necessarily dependent on the origin of wood unlike Finnish professionals and laymen (familiarity to wood). The result of correlation analysis explained that the preference was generally based on the visual impression, the degree of processing as well as atmosphere of wood. For instance, students and normal workers preferred wood with oil finishing even though normal workers clearly avoided heartwood of Japanese cedar. On the other hand, architects preferred heartwood of Japanese cedar and interior designer preferred white wood with natural surface though both clearly avoided wood with oil finishing. In the preference of both professionals and laymen, the different factors were observed.

The latent selective factors were investigated based on the result from PCA, the preference and the correlation analysis. The elements related to physical properties of wood could be commonly seen as the cognitive elements. The difference in the factors was that students also recognized wood from the point of "secular change" and normal workers chose wood in terms of "ligneous". Each selective factor of professionals and laymen was as follows. Student: tone of color, heaviness, shape of grain, secular change, yellowishness, surface condition. Normal worker: tone of color, light and shade of color, interval of grain, ligneous. Architect: light and shade of color, heaviness, familiarity, surface condition, degree of processing. Interior designer: tone of color, light and shade of color, heaviness, stiffness, interval of grain, whiteness, yellowishness.

\section{Conclusion}

In this paper, at least 10 latent selective factors when Japanese design professional and laymen choosing wood for living space were revealed. These latent selective factors were related to color tone, light and shade of color, whiteness, yellowishness, heaviness, stiffness, shape and interval of grain, surface condition, degree of processing secular change, ligneous, and familiarity. In a future study, the effective measures for the utilization of domestic wood and the guideline to design wooden architecture will be investigated based on both studies from Japanese and Finnish professionals and laymen. 